УДК 341.63

DOI https://doi.org/10.32837/pyuv.v0i1(30).550

\author{
B. І. Нагнибіда \\ orcid.org/0000-0003-4233-7173 \\ кандидат юридичних наук, доцент, \\ старший науковий співробітник \\ Науково-дослідного інституту приватного права \\ і підприємниитва ілені акаделіка Ф. Г. Бурчака \\ Національної академії правових наук України
}

\title{
ЕФЕКТИВНИЙ ЗАХИСТ ЯК ЦІЛЬ ПРАВОЗАСТОСУВАННЯ В МІЖНАРОДНОМУ КОМЕРЦІЙНОМУ АРБІТРАЖК
}

Останнім часом у теорії і практиці захисту прав та інтересів прийнято говорити про ефективний захист. Концепція ефективного захисту дедалі глибше проникає в юриспруденцію, судову практику та на сторінки юридичних видань. Не є виключенням і сфера міжнародного комерційного арбітражу, де захист порушених, невизнаних та оспорюваних прав є однією з основних цілей арбітражного розгляду. Це пов'язано з тим, що міжнародний комерційний арбітраж як альтернативний спосіб вирішення міжнародних комерційних спорів покликаний врегулювати розбіжності між його сторонами. Подібно до того, як суди, відправляючи судочинство, здійснюють захист майнових і немайнових прав та інтересів фізичних i юридичних осіб, міжнародні арбітражі, постановляючи арбітражні рішення, вирішують спори між учасниками міжнародних комерційних угод. Однак нині через завантаженість судів та зростаючу кількість справ у міжнародних комерційних арбітражах, а також з огляду на складність спорів саме ефективність відправлення правосуддя та арбітражного розгляду, ефективність засобів юридичного захисту набуває визначального значення.

Порівняно з судовим захистом, міжнародний комерційний арбітраж традиційно вирізняється більш ефективними процедурами, більш короткими строками розгляду і вирішення спорів, незалежністю та неупередженістю арбітрів, конфіденційністю, більш високими показниками виконання арбітражних рішень. Разом із тим у світлі вдосконалення процедур вирішення спорів в арбітражі, конкуренції між провідними арбітражними установами світу, впровадження нових прогресивних технік у вирішенні спорів, питання ефективності захисту прав арбітражами постає в новому світлі. 3 іншого боку, розвиваючись переважно у площині правозастосовної практики, усі техніки ефективності мають нині прикладний характер, не отримуючи наукового та теоретичного осмислення. Тому їх доктринальне дослідження має важливе значення для розуміння концепції ефективності процесуальних засобів у праві загалом та міжнародному приватному і процесуальному праві зокрема.
Варто зазначити, що вивченням ефективності засобів захисту у сфері міжнародного комерційного арбітражу уже частково займались такі українські вчені та практики, як Л.Ф. Винокурова, Т.Г. Захарченко, О.Д. Крупчан, М.М. Мальський, О.С. Перепелинська, І.Г. Побірченко, Ю.Д. Притика, М.Ф. Селівон, Т.В. Сліпачук, Г.А. Цірат, Ю.С. Черних, В.С. Щербина та інші. Однак нині є потреба у формуванні уніфікованого підходу до розуміння концепції ефективності в міжнародному комерційному арбітражі з метою вдосконалення механізму правозастосування.

Тому метою цієї статті є формування основних наукових засад розуміння ефективності захисту у сфрері вирішення міжнародних комерційних спорів арбітражами.

Як відомо, арбітраж із позиції очікувань учасників міжнародного комерційного обороту, сучасного стану його розвитку та останніх викликів, які постали перед цим інститутом альтернативного вирішення спорів, є ефективним інструментом захисту прав учасників міжнародного комерційного обороту. У найбільш загальному вигляді його мета і завдання полягають у тому, щоб ефективно вирішити спір та на основі постановленого рішення захистити порушені права сторін спору. Тому у світлі теорії правозастосування можна виділити два елементи, які з точки зору користувачів його послугами мають охоплюватись метою і завданнями арбітражу та арбітражного розгляду: перший стосується ефективності арбітражного розгляду, а другий - можливості реального виконання постановленого арбітражного рішення з метою захисту прав учасників спору. За наявності обох елементів матиме місце ефективний захист порушених прав сторони спору. Подібний зміст витікає також й зі ст. 2 ЦПК України [1] та ст. 2 ГПК України [2], в яких завданнями цивільного та господарського судочинства визначено справедливий, неупереджений та своєчасний розгляд $i$ вирішення спорів із метою ефективного захисту порушених, невизнаних або оспорюваних прав, свобод чи інтересів фізичних осіб, прав та законних інтересів юридичних осіб, держави. 3 огляду на те, що мета і завдання судового та арбітражного способу вирі- 
шення спорів є подібними, видається, що питання ефективного захисту порушених, невизнаних або оспорюваних прав, свобод чи інтересів учасників міжнародного комерційного обороту є також актуальним для арбітражного порядку розгляду спорів. Зрештою, обидва механізми вирішення спорів хоча й і є різними формами вирішення спорів, але як судовий захист, так і арбітражний розгляд спрямовані на захист порушених, невизнаних або оспорюваних прав, свобод чи інтересів сторін спорів. Тому для визначення мети арбітражного розгляду та правозастосування варто визначитись із питанням, що становить зміст поняття «ефективний захист» .

Говорячи про ефективний захист, зазначимо, що у сфері арбітражу він різними авторами пов'язується або з ефективною процедурою, або з якістю рішення, яке має стати обов'язковим для сторін (бути правильним і відповідати встановленим вимогам) та бути виконуваним (be executable or enforceable) [3, c. 691-692]. Разом із тим у теорії apбітражного процесу відсутні детальні положення щодо ефективного захисту в арбітражі, що може бути предметом подальших наукових досліджень. Зазначимо, що нині найбільш фундаментально це поняття сформульоване в теорії і практиці захисту прав людини, де «ефективний захист» пов' язується, передусім, зі змістом ст. 13 Європейської конвенції про захист прав людини і їі основоположних свобод [4], за якою «кожен, чиї права та свободи, визнані в иій Конвениї, було порушено, лає право на ефективний засіб юридичного захисту в національнолу органі...». Ефективність засобу юридичного захисту в практиці Європейського суду з прав людини пов'язується з такими його характеристиками, як доступність (availability), достатність (sufficiency), визначеність (certainty). $\mathrm{У}$ процесі оцінки ефективності беруться до уваги не лише формальні засоби захисту (та їх доступність, достатність і визначеність - B.Н.), але й загальний правовий та політичний контексти, в якому вони функціонують та конкретні обставини справи заявника, незалежність таких заходів захисту від дій держави тощо. При цьому ефективність не залежить від визначеності бажаного для заявника результату [5;6].

3 огляду на вказані критерії, а також концепцію ефективного правового засобу захисту, що є в європейському праві [7; 8], видається, що ефективним вважатиметься такий засіб юридичного захисту, який є доступним і забезпечує особі реальний (а не ілюзорний) захист іiі порушених прав [9; 10], може бути практично реалізованим $[11 ; 12]$, визначеним у національній правовій системі [13], реально застосовуваним і можливість його використання не може бути невиправдано ускладнена діями або бездіяльністю органів влади $[14 ; 15]$, застосованим протягом розумно- го часу (reasonable time), тобто своєчасним [16]. Як бачимо, вказана концепція спирається на базові елементи: 1) доступність засобу; 2) реальність захисту (неілюзорність, правова визначеність та дієвість); 3) розумність витрат часу. Видається, що зазначені елементи з огляду на спільність мети судового та арбітражного захисту є базовими для формування концепції ефективного захисту і в арбітражі, а також придатними для визначення мети і завдань арбітражного розгляду. Крім цього, можливість застосування положень ст. 13 Конвенції у світлі формування концепції ефективного захисту в арбітражі випливає 3 низки інших висновків, що містяться в рішеннях ЄСПЛ. Так, Суд вказує на відсутність встановлення ст. 13 Конвенції конкретних вимог для Держав-учасниць стосовно визначення певних форм для способів захисту - держави користуються свободою визначати такі способи захисту на власний розсуд $[17 ; 18]$. Також згаданим у ст. 13 «органом» не обов'язково має виступати державний суд [19]. Тому можна стверджувати, що закріплені на нормативному рівні та інтегровані в національну правову систему альтернативні способи вирішення спорів варто розглядати як способи захисту в розумінні ст. 13 Конвенції. Звідси і вимоги до забезпечення ï ефективності, що досягається дотриманням сукупності встановлених вище елементів.

У світлі сказаного видається, що міжнародний арбітраж як раз і є тим засобом правового захисту, до якого звертаються сторони, підписуючи арбітражну угоду. Його ефективність залежить не лише від «ефективного» арбітражного розгляду, який зазвичай врегульовується Регламентом. Тим більше, що в такому разі варто говорити не стільки про ефективність арбітражного розгляду конкретного спору, скільки про збалансованість і ефективність використовуваного сторонами Регламенту і про те, наскільки передбачені ним процедури та процесуальні дії є розумними (reasonable and fear) з позиції їх доступності сторонам, достатності для потреб захисту порушених прав, визначеності та ефективними з точки зору витрат часу і коштів сторін (time and cost efficient). Значною мірою ефективність арбітражу залежить від поведінки самих сторін спору та їх юридичних радників, складу арбітражу, а також характеру і складності справи та положень права, застосовуваного до арбітражного розгляду (lex arbitri). Адже, які б ефективні процедури не були закладені в Регламенти, незнання їх Сторонами спору та їх представниками, чи небажання їх використовувати з метою затягування процесу, або ж з метою формування доказів для подальших юрисдикційних заперечень у судах місця арбітражу, так само як і оцінка складом арбітражу наданих доказів, юрисдикційних заперечень тощо, можуть 
суттєво впливати як на швидкість арбітражного розгляду, так і на ефективність захисту стороною своїх прав.

Беручи до уваги вищенаведене, під час формулювання мети арбітражного розгляду та мети правозастосування варто відштовхуватись від цілі, з якою арбітраж як засіб юридичного захисту обирався сторонами - захист порушених, невизнаних чи оспорюваних прав та інтересів сторони. Звісно, що такий захист мав бути ефективним у самому широкому розумінні з урахуванням усіх згадуваних вище складових елементів концепції ефективного засобу захисту. За такого підходу забезпечення ефективного арбітражного розгляду буде лише одним з елементів ефективного захисту, однак не єдиним, оскільки для забезпечення реальності правового захисту в арбітражі важливе значення мають правильність та виконуваність рішення, постановленого за результатами арбітражного розгляду, що і буде предметом подальших наукових досліджень.

\section{Iimepamypa}

1. Цивільний процесуальний кодекс України від 18.03.2004 р. № 1618-IV. Верховна Рада України. Законодавство України. URL: https://zakon.rada.gov. ua/laws/show/1618-15.

2. Господарський процесуальний кодекс України від 06.11.1991 р. Верховна Рада України. URL : https://zakon.rada.gov.ua/laws/show/1798-12.

3. Kirby J. Efficiency in International Arbitration: Whose Duty Is It? Journal of International Arbitration. 2015. Vol. 32. No. 6. Pp. 689-696.

4. Convention for the Protection of Human Rights and Fundamental Freedoms of 4 November 1950. United Nation Treaty Collection. URL: https://treaties.un.org/ doc/Publication/UNTS/Volume $\%$ 20213/volume-213-I2889-English.pdf.

5. Guide sur l'article 13 de la Convention européenne des droits de l'homme: Droit a un recours effectif (31 Octobre 2019). Conseil de l'Europe / Cour européenne des droits de l'homme. URL: https://echr.coe.int/Documents/ Guide Art 13 FRA.pdf.

6. Guide to Good Practice in Respect of Domestic Remedies, adopted by the Committee of Ministers of member States of the Council of Europe on 18 September 2013. Council of Europe : Directorate General. URL: https://www.echr.coe.int/Documents/Pub_coe_domestics remedies ENG.pdf.

$\overline{7}$. Piatek $\overline{\mathrm{W}}$. The right to an effective remedy in European law: significance, content and interaction. China-EU Law Journal. 2019. № 6. Pp. 163-174. URL: https://rdcu.be/b3FA0;

8. Improving access to remedy in the area of business and human rights at the EU level : Opinion of the European Union Agency for Fundamental Rights (1/2017, as of April 10, 2017, Vienna). The European Union Agency for Fundamental Rights (FRA). URL: https://fra.europa.eu/ sites/default/files/fra uploads/fra-2017-opinion-012017-business-human-rights_en.pdf.

9. Judgment of 7 July 1989: Case of Soering v. The United Kingdom: Apl. № 14038/88. European Court of Human Rights. URL: http://hudoc.echr.coe.int/ rus? $\mathrm{i}=001-57619$;
10. Judgment of 15 November 1996: Case of Chahal v. The United Kingdom: Apl. № 22414/93. European Court of Human Rights. URL: http://hudoc.echr.coe.int/ rus? $\mathrm{i}=001-58004$.

11. Judgment of 10 September 2010: Case of McFarlane v. Ireland: Apl. № 31333/06. European Court of Human Rights. URL: http://hudoc.echr.coe.int/ rus? $\mathrm{i}=001-100413$;

12. Judgment of 19 February 1998: Case of Kaya v. Turkey: Apl. № 158/1996/777/978. European Court of Human Rights. URL: http://hudoc.echr.coe.int/ rus? $\mathrm{i}=001-58138$;

13. Judgment of 4 May 2000: Case of Rotaru v. Romania: Apl. № 28341/95. European Court of Human Rights. URL: http://hudoc.echr.coe.int/rus?i=001-58586.

14. Judgment of 25 September 1997: Case of Aydin v. Turkey: Apl. № 57/1996/676/866. European Court of Human Rights. URL: http://hudoc.echr.coe.int/ rus? $\mathrm{i}=001-58371$;

15. Judgment of 28 July 1998: Case of Ergi v. Turkey: Apl. № 66/1997/850/1057. European Court of Human Rights. URL: http://hudoc.echr.coe.int/ rus? $\mathrm{i}=001-58200$.

16. Judgment of 8 June 2006: Case of Sürmeli v. Germany: Apl. № 75529/01. European Court of Human Rights. URL: http://hudoc.echr.coe.int/rus?i=001-75689.

17. Judgment of 30 October 1991: Case of Vilvarajah and others v. The United Kingdom: Apl. № 13163/87; $13164 / 87 ; 13165 / 87 ; 13447 / 87 ; 13448 / 87$. European Court of Human Rights. URL: http://hudoc.echr.coe.int/ rus? $\mathrm{i}=001-57713$;

18. Judgment of 12 May 2000: Case of Khan v. The United Kingdom: Apl. № 35394/97. European Court of Human Rights. URL: http://hudoc.echr.coe.int/ rus? $\mathrm{i}=001-58841$.

19. Judgment of 26 October 2000: Case of Kudla v. Poland: Apl. № 30210/96. European Court of Human Rights. URL: http://hudoc.echr.coe.int/rus?i=001-58920.

\section{Анотація}

Нагнибіда В. I. Ефективний захист як ціль правозастосування в міжнародному комерційному арбітражі. - Стаття.

У статті досліджуються питання ефективності міжнародного комерційного арбітражу та ефективного правового захисту. У світлі практики Європейського суду з прав людини автор досліджує сучасні підходи до розуміння ефективності в праві. Встановлено, що ефективність засобу юридичного захисту зазвичай пов'язується 3 такими його характеристиками, як доступність, достатність, визначеність. При цьому під час оцінки ефективності враховуються також загальний правовий та політичний контексти, в яких вони функціонують, та конкретні обставини справи заявника, незалежність таких заходів захисту від дій держави тощо. На основі аналізу автором зроблено висновок, що міжнародний арбітраж як раз і є тим ефективним засобом правового захисту, до якого звертаються сторони, підписуючи арбітражну угоду. Його ефективність як способу вирішення комерційних спорів та захисту прав учасників міжнародних відносин залежить не лише від «ефективного» арбітражного розгляду, який зазвичай врегульовується Регламентом. У розумінні ефективної арбітражної процедури варто виділяти збалансованість і ефективність використовуваного сторонами Регламенту і те, наскільки передбачені ним процедури та процесуальні дії є розумними з позиції їх доступності сторонам, достатні для потреб захисту порушених 
прав, визначені та ефективні з точки зору витрат часу i коштів сторін. При цьому автором обгрунтовано, що ефективність арбітражу залежить від поведінки самих сторін спору та їх юридичних радників, складу арбітражу, а також характеру і складності самої справи та положень права, застосовуваного до арбітражного розгляду (lex arbitri). Адже, які б ефективні процедури не були закладені в Регламенти, незнання їх Сторонами спору та їх представниками, чи небажання їх використовувати з метою затягування процесу, або ж з метою формування доказів для подальших юрисдикційних заперечень у судах місця арбітражу, так само як і оцінка складом арбітражу наданих доказів, юрисдикційних заперечень тощо, можуть суттєво впливати як на швидкість арбітражного розгляду, так і на ефективність захисту стороною своїх прав.

Ключові слова: правозастосування, міжнародний комерційний арбітраж, ефективність правового захисту, практика ЄСПЛ, засіб правового захисту.

\section{Summary}

Nahnybida $V$. I. Effective protection as a law enforcement goal in international commercial arbitration. - Article.

The article examines the issue of effectiveness of international commercial arbitration and the effective legal protection. In the light of the case law of the European Court of Human Rights, the author explores current approaches to understanding effectiveness in law. It is established that the effectiveness of a legal remedy is usually associated with such characteristics as availability, sufficiency, certainty. Herewith, in assessing the effectiveness one also takes into account the general legal and political contexts in which they operate and the specific circumstances of the applicant's case, the independence of such remedies against State action and the like. On the basis of the analysis, the author concludes that international arbitration is the effective legal remedy to which the parties apply by signing the arbitration agreement. Its effectiveness as a way of resolving commercial disputes and protecting the rights of participants in international relations depends not only on the "effective" arbitration proceedings that are usually governed by the Rules. Understanding the effective arbitration procedure, the balance and effectiveness of the rules used by the parties should be distinguished, and the extent to which the procedures and procedural measures envisaged by them are reasonable in terms of their accessibility to the parties, sufficient for the protection of the violated rights, determined and effective in terms of the parties' time and expense. The author argues that the effectiveness of arbitration depends on the behavior of the parties to the dispute and their legal advisers, the composition of the arbitration tribunal, as well as the nature and complexity of the case itself and the provisions of the law applicable to arbitration (lex arbitri). After all, whatever effective procedures are laid down in the Rules, ignorance of such Rules by the Parties and their representatives, or their unwillingness to use them to delay the process, or to produce evidence for further jurisdictional objections in the courts at the place of arbitration, as well as the assessment by the arbitration tribunal of evidence, jurisdictional objections, etc. can have a significant impact on both the speed of the arbitration and the effectiveness of the party's defense of its rights.

Key words: law enforcement, international commercial arbitration, effectiveness of legal protection, ECtHR practice, legal remedy. 